Published by the UFS

http://journals.ufs.ac.za/index.php/trp

(c) Creative Commons With Attribution (CC-BY)

How to cite: de Beer S. \& Oranje, M. 2019. City-making from below: A call for communities of

resistance and reconstruction. Town and Regional planning, no.74, pp. 12-22.

\section{City-making from below: A call for communities of resistance and reconstruction}

\section{Stephan de Beer \& Mark Oranje}

\section{DOI: $h t t p: / / d x . d o i . o r g / 10.18820 / 2415-0495 / t r p 74 i 1.2$}

Revised April 2019, Published 30 June 2019

*The authors declared no conflict of interest for this title or article

\begin{abstract}
This article laments the exclusion of small, local communities, voices and visions, from participating in making the city. It makes a case for 'small communities' practising resistance and reconstruction in multiple ways and places. Instead of viewing such actions as naïve or a-political, it calls for an understanding of such practices as alternatives to 'top-down' urban processes, and, as such, representing a different and necessary, critical political imagination. In doing so, it fuses insights from equity planning theories, praxis-based liberation theological approaches, and emancipatory community development approaches. It argues that communities, aware of the forces that would seek to tear them apart, can play a significant role in making cities 'from below'. This, it is argued, would be even more possible through such communities finding each other, and nurturing deep solidarities, until broad-based, interconnected movements take shape, embodying concrete signs of wholeness.
\end{abstract}

Keywords: Equity planning, political imagination, reconstruction, resistance

\section{STADSBOUPROSSESE 'VAN ONDER AF': 'N OPROEP VIR GEMEENSKAPPE VAN WEERSTAND EN REKONSTRUKSIE}

Die artikel betreur die uitsluiting van klein plaaslike gemeenskappe, stemme en visies van deelname in stadsbouprosesse. 'n Saak word gemaak vir 'klein gemeenskappe' wat op verskeie maniere en in verskillende plekke weerstand bied en heropbou. In plaas daarvan om sulke praktyke as naïef of a-polities te sien, maak die artikel 'n oproep tot die verstaan van sulke praktyke as alternatiewe tot stedelike prosesse 'van bo af', en as verteenwoordigend van 'n ander en noodsaaklike, kritiese politieke verbeelding. In die proses vermeng dit insigte van ekwiteitsbeplanningsteorieë, praxis-gebaseerde bevrydingsteologieë, en emansiperende gemeenskapsontwikkelingsprosesse. Daar word gesuggereer dat gemeenskappe, bewus van die kragte wat hulle wil verdeel, 'n betekenisvolle rol kan speel in stadsbouprossese 'van onder af'. Die bewering word gemaak dat dit selfs meer moontlik sou wees as sulke gemeenskappe mekaar sou vind en 'n diep solidariteit met mekaar sou kweek, totdat breë-gebaseerde, verbinde bewegings vorm begin aanneem, en konkrete tekens van heelheid beliggaam.

Sleutelwoorde: Ekwiteitsbeplanning, heropbou, politieke verbeelding, weerstand

\section{KETSO/THEO YA TOROPO \\ HO TSWA HO TSE TLASE: \\ MEMO/PITSO YA DITJHABA YA KGANYETSO LE KAHO BOTJHA}

Atikele ena e lla/tletleba ka ho tlohellwa kantle ha ditjhaba tse nnyane tsa selehae, mantswe a tsona le pono ya tsona, ho nkeng karolo bakeng sa ho etsa/thea toropo. Atikele e etsa nyewe bakeng sa "ditjhaba tse nnyane" tse etsang kganyetso le kaho botjha ka mekgwa e mengata le dibakeng tse ngata. Ntle le ho sheba di ketsahalo tse tjena jwalo ka tse se nang boiphihlelo kapa tsa sepolotiki, ho batlahala kutlwisiso diketsahalong tse tjena, jwalo ka dikgetho bakeng sa mekgwa ya setoropo ya ho tloha hodimo ho ya tlase (top-down urban processes), mme ka mokgwa oo, e tlisa dipono ho tswa ho ditheori tsa thero tekano, mekgwa ya theori ya tokoloho e itshetlehileng hodima praxis (praxis-based liberation theoretical approaches), le mekgwa ya ntshetsopele ya setjhaba sa tokoloho (emancipatory community development approaches). Atikele ena e hlalosa hore ditjhaba, tse elang hloko matla a ka batlang ho di kgaola ka lehare, di ka bapala karolo ya bohlokwa bakeng sa ho etsa ditoropo "ho tswa tlase". Ho ngangisanwa ka hore sena se ka kgonahala haholo ka hore ditjhaba di fumanane/fihlellane, hape le ho hodisa kopano e tiileng, ho fihlella mekgatlo e kopaneng e nka sebaka; e bontsha matshwao a tsitsitseng a kopano.

\section{INTRODUCTION}

This article focuses on communities that are often neglected or marginalised in terms of their access to urban resources, their participation in planning processes that affect them, and their audibility in terms of voicing issues that might be of grave concern to them.

It engages the need for including such communities in the making and remaking of the city. In doing so, it concurs with Shaper (1989: 120) that "small communities" - those generally lacking access to resources and power - hold the key to radical change. In South Africa, this might very well be the majority of

Prof. Stephan (S.) de Beer, Associate Professor of Practical Theology, Director, Centre for Contextual Ministry, Faculty of Theology, and Ph.D. Student, Department of Town and Regional Planning, University of Pretoria, Pretoria, 0028, South Africa. Phone: 012-420-4952, e-mail: <stephan. debeer@up.ac.za> ORCID: https://orcid.org/0000-0002-8614-099X

Prof. Mark (M.) Oranje, Department of Town and Regional Planning, University of Pretoria, Pretoria, 0028, South Africa. Phone: 012-420-3535, e-mail: <mark.oranje@up.ac.za> ORCID: https://orcid.org/0000-0003-4844-4025

SSB/TRP/MDM 2019 (74):12-22 ｜ＩSSN 1012-280｜ｅ-ISSN 2415-0495 
communities. Ending homelessness, reclaiming schools, or building housing for so-called "un-houseables" can be done by communities, once they "take back the powers they have given away", because they understand that it is in the interest of their life together to do so. Fighting for their lives and livelihoods, communities are able to do what municipalities and the private sector often will not and cannot do.

The article flows from Ph.D. research ${ }^{1}$ that concerned itself with the ways in which certain (inner city) communities are excluded from city-making processes; decisions and plans made about them without their participation; and planning (professionals) generally disconnected from the narratives, struggles and aspirations of these communities. Fusing insights from equity planning theories ${ }^{2}$ with praxis-based liberation theological approaches $^{3}$ and emancipatory community development processes, ${ }^{4}$ it suggests that planning is not as equitable as it purports to be, but is biased in the direction of those where power and resources concentrate. To address this, the article proposes community-owned planning processes in which communities themselves practise resistance and reconstruction, thereby contributing to city-making in concrete ways, from below.

Before elaborating on the idea of both resistance and reconstruction, the article grounds these community-based practices in a different political imagination, to be animated in local communities, embracing a sense of agency and urgency. It concludes by imagining

1 De Beer (2018).

2 We draw on the work of equity planning theorists such as Krumholz and Clavel (1994), Metzger (1996) and Krumholz and Hexter (2019).

3 Liberation theologies, opting for poor and oppressed communities, critiqued developmental approaches that create dependency and under-development. Scholaractivists such as Shannahan (2013), Hankela (2014) and Nixon (2014) have appropriated liberation theologies for the struggles of local urban communities.

4 Ledwith $(2007 ; 2011)$ and Coburn and Gormally (2015) consider emancipatory approaches to community development whereas DeFilippi and North (2004) offer a critical appreciation of such approaches. a movement of interconnected communities, celebrating resistance and longing/working for wholeness.

\section{A DIFFERENT POLITICAL IMAGINATION: PRACTISING RESISTANCE AND RECONSTRUCTION}

A different political imagination is required, with small communities at the bottom of the urban ladder, if they are to be truly included as participants in urban processes, beneficiaries of urban resources, and contributors to urban well-being. In this instance, "different" is meant in the sense of shifting from expecting external intervention through planners or politicians to an embrace of the urgency to take action as local communities themselves.

This article argues that small communities practising resistance and reconstruction could contribute meaningfully to city-making from below. ${ }^{5}$ Furthermore, a proliferation of such communities, collaborating through building collective solidarity, have the potential to become significant urban movements, embodying such a different political imagination.

The communities referred to - even though perhaps small and powerless, at first sight - are those in which people and local institutions start to organise themselves, take collective ownership for their own well-being and futures, and build agency and capacity to effect local change that is in the interest of a greater, common good. Once they take charge of their life together and imagine a new future on their own terms, such communities will be able to mediate change from within. Such changes, once made, could be viewed as local irruptions from within, or, what Pieterse \& Simone (2013: 15) refer to as the "rogue intensities" that open creative new spaces from below, and

5 In this instance, "from below" is used in the context of city-making. It draws on the work of Giroux (1988) on pedagogy and political empowerment; the works of Freire (2007; 2014), but, in the context of the present article even more importantly, Freire (1993), and the work of Rocke and Van Dyke (2012) on doing theology from below in hard urban places. go against the flow of conventional dominant urban discourses or practices, driven down from above.

To have such power in the face of, and against the powers "pushing down on them" from above, and to sustain and spread such power from below, these small and emerging narratives and practices of local communities need to be supported, strengthened and broadcast. This is always important, but even more so in situations where urban reconstruction processes, led by the public or private sector, mostly fail to address a local community's concerns and challenges or consider its visions and aspirations. Such local narratives or irruptions can emerge in many forms, and be expressed in the actions of faith-based groups, organised civil society, individual change-makers, third sector organisations, or resident groups, that found it within themselves to resist oppressive forces seeking to steal their soul or take their land.

However, the small and local expressions of communitybased urban action referred to in this instance are neither naïve nor a-political. Instead, such alternatives to conventional topdown urban processes should be understood as a different and indeed, at times, essential and critical, political imagination.

The work of the Catholic political theologian, Emmanuel Katongole (2011: 59-62) develops a strong critique of the nation-state in its current form in Africa. He argues for an investment of intellectual and other capacities, not in a "preoccupation with fixing broken institutions" (Katongole 2011: 60), but rather in the imagination and incubation of "new experiments" (Katongole 2011:60) and "other forms of social structure outside the nation state" (Katongole 2011:59).

Katongole (2011: 62 ) opines that we need more "story-tellers" who are able to demonstrate the possibility of alternatives, and not necessarily more "experts and technical aides". Such story-tellers "involve an investment of bodies and are 
thus a unique political imagination" (Katongole, 2011: 62). Such embodied practices and narratives often organically responding as acts of resistance to urban exclusions or oppressions - should be advocated for in relation to urban planning and city-making processes.

In this pursuit, the roles and mandates of local governments or professional planners in city-making processes are not negated. There is a strong argument for broad-based and innovative collaborations, in which local communities will play a much stronger leadership role in co-determining city-making processes and outcomes, and in keeping professionals and politicians accountable. It is argued that communities need planners (to help conceptualise, articulate, and amplify local concerns, visions and ideas) and planners need communities (to be sensitized, informed and kept accountable).

\section{FROM LOCAL COMMUNITY IRRUPTIONS TO NETWORKED MOVEMENTS OF HOPE}

A critique often levelled at localised interventions or change-making, also in urban communities, is that such interventions have limited impact, and fail to bring about the structural changes that plague cities and especially the urban poor (Watson, 2002: 43). However, a deliberate embrace of 'the small and local' is recognised and advocated as a different political imagination, not functioning in isolation, but deeply embedded locally, whilst at the same time deeply (inter) connected elsewhere and globally. It seeks to affirm and appreciate embodied alternative imaginaries, practised sustainably by small, local communities, as perpetual challenges to dominant narratives, demonstrating the possibility of such alternatives, despite the odds being stacked against them.

For deep, structural and sustained change to occur, it becomes necessary for small communities to act together in networked and collaborative ways. This requires of small communities to connect to other small communities, different geographical areas to organise themselves into city-wide alliances, and intersectional urban issues to find synergy in their similar and collective struggle for urban justice. As such, these pointers echo Harvey's (2012: xii) appreciation for "the right to the city movements ... active in dozens of cities around the world". Harvey (2012: xiii) suggests that these movements must "rise up", not so much as intellectual responses to urban challenge, but "from the streets, out of the neighbourhoods, as a cry for help and sustenance by oppressed people in desperate times". Such movements hold the potential to mediate viable and radical urban alternatives through deep structural change.

Urban social movements often remain active only within the narrow base of their singular issues or local geographical areas. However, without participation in broader movements, the breadth and depth of the urgent changes required would not occur. One would perceive only ad hoc local transformations without gaining the kind of momentum that can offer adequate resistance to dominant discourses and practices of the neo-liberal capitalist city.

Harvey (2012: xviii) clearly states that "the ultimate task is to overthrow those practices through a much broader revolutionary movement". To accomplish this, Harvey (2012: 25) refers to a "multitude of diverse urban struggles and urban social movements already in existence", that are innovative in addressing issues ranging from environmental sustainability to the integration of migrants and the urban design for public or social housing. According to him, there is a deep interconnectedness between "an economy of wealth accumulation" and "an economy of dispossession" (Harvey, 2012: 25). "Wealth accumulation" is a form of violence that requires the dispossession of some. As cure for this, Harvey (2012: xviii) argues that "(t)he whole capitalist system of perpetual accumulation, along with its structures of exploitative and class power, has to be overthrown and replaced". This is not an overnight project. It requires at the current point of dispossession that the dispossessed must not only be reminded of their humanity and, therefore, right to the city, but also need to be supported as they rise to resist exclusion and "to reinvent the city more after their hearts' desire" (Harvey, 2012: 25).

Taking its cue from Harvey, what hence seems to be necessary is for a continuum of resistance and reconstruction to be ignited and sustained. In this article, 'urban hope' - in the sense of increased access, freedom and justice for excluded communities - gets located in those small, local and deliberately interconnected spaces where alternative urban imaginations could be discovered, nurtured, practised, deepened and developed. In this way, both small and local, as well as interconnected and global communities and movements emerge as mediators of hopeful new cities.

\section{ON RESISTANCE}

\subsection{Rhetoric, respectability or resistance}

In post-apartheid South Africa, there has been an allergic reaction towards resistance, quickly labelling those resisting the lack of good governance, neoliberal capitalism, and pervasive forms of corruption as 'counter-revolutionaries'.

Being co-opted into the myth of rainbow neutrality, for a moment South Africa faced the weakening of a vibrant civil society, oppositional politics or active faithbased resistance. The rhetoric of liberation-transformationrevolution crept into public policy documents, parliamentary and party-political discourse, and informal conversations on the street, but the complete disconnect between rhetoric and actuality was often nauseating, seeing how the 
gaps of inequality were widening while the rhetoric flourished.

In a paper on the Situationist City, Swyngedouw (2002: 153) reflects critically on what he calls the "respectability" of what used to be radical movements of transformation. In a rather cynical fashion, Swyngedouw (2002: 154) suggests that it is "the fate of any revolutionary political or urbanutopian movement and moment to become celebrated when the political and social threat emanating from it seems to have run out of steam". In accordance with this view, it is possible for movements of revolution to be co-opted by other powers once they have achieved the initial victory, or the initial sociopolitical threat has been overcome.

In the South African landscape, this is now clearer than ever. Despite recent positive changes at the top, it has literally become a battle for the soul of a nation and the soul of its cities. How this battle plays itself out at the level of a metropolitan municipality is disturbingly narrated by Olver (2017) in his account of the battle for the resources, power base and, indeed, the soul of Nelson Mandela Bay. In this regard, Swyngedouw (2002: 154) reminds us that real transformation is never merely academic discourse or acts of respectable rhetoric acted out in classrooms or in parliament buildings "Revolution is acted out in the streets”, Swyngedouw (2002: 154) argues, and as such it is a "decidedly geographical", spatial and urban affair. Considering the Nelson Mandela Bay narrative (Olver, 2017: 231-243), resistance or a commitment to transformation is also a decidedly messy affair, requiring a robustness that would not always seem respectable or respectful, especially when contending with dark and corrupt forces at play.

However, in recent times, we have seen the emergence of robust activist movements - in Parliament, on university campuses, in cities, towns and local communities disregarding the "respectability" of power, resisting the monopolizing of space by some at the expense of the many, reclaiming public and political spaces, becoming a massive voice that cannot be missed. In the South African ntext, movements emerged $^{6}$ that respond creatively to a myriad of issues ranging from access to health and equal education, to gender and LGBTIQ concerns, a right to the city, and a right to water and sanitation.

For as long as some are excluded from economic and social access, and not allowed to participate fully in the processes of reconstruction, creative and constructive resistance remains a valid and required response. Transformation and reconstruction will remain buzzwords only, if not continuously preceded or accompanied by ever-deepening processes of socio-economic liberation.

Planners and urban practitioners, as well as "innocent" communities of hope, would do well to learn from the engagements and practices of more robust social movements, in terms of organising strategies and tactics for resistance and change-making. Global and local social movements are as much movements of resistance to that which threatens to kill the soul of nations, cities and communities, as they are about seeking constructive alternatives in their respective fields. They should not be disregarded, but attentively considered.

\subsection{Marginality as "site of resistance"}

As local communities, citizens' organisations, planners and others concerned with the well-being of our cities immerse themselves in various neighbourhoods, they are often confronted with marginality. On close inspection, one grasps that people and neighbourhoods are

6 Ballard, Habib \& Valodia (2006) reflect on social movements in post-apartheid South Africa; Madlingozi (2017) speaks of social movements' quest for the elusive 'new' South Africa; Gastrow (2015) considers "a new civil society", and De Beer (2017) gives special attention to the meaning of urban social movements for the church and theological education. usually not marginalized by choice, but because of systemic exclusions, external to themselves. Watson and Gibson (1995: 257-261) show how deviation from the cultural norm or dominant narrative, coupled with a lack of economic or political power, often leads to marginalization, in terms of access to both physical location and resources for well-being.

Communities of hope often choose marginality, because they choose to be in solidarity with marginal people and places. Such a choice is simultaneously, sometimes unknowingly, a "site of resistance" (Hooks, 1999: 22), and participation in resistance. Once individual planners, community practitioners or engaged researchers make such a choice, they might also experience personal or institutional marginality, either subtly or overtly. They might have to decide whether to succumb to the dominant narrative, resign into apathy, or live consciously, and sacrificially even, resisting the dominant narrative, in order to help usher in multiple small transformations in small, local places. Even "innocent" community developers or city planners, if living with conscience and concerned with justice, when exposed to marginality, are faced with a choice. Those moments of decision determine the integrity with which we embrace and embody our deepest callings and (professional) vocations.

\subsection{Beyond isolation: The imperative of intersectionality}

Many of the activist movements that have emerged in recent years on the South African landscape have become very sophisticated in their practices and achieved visible results. Yet, the isolation or segregation of different movements from one another - even though the root causes of the issue they advocate might be the same - significantly hinder advancement of a radical agenda. The conversation around intersectionality becomes very important in this context. Scholars such as Crenshaw (1989) assert that race, class and gender are 
"intersecting oppressions" and that the strategies and tactics to address such oppressions increasingly need to be interconnected in a deliberately intersectional manner. The liberation theologian Leonardo Boff (1997) speaks of the ways in which the cries of the earth, the poor and women, are, in essence, the same cry, caused by the common denominator of patriarchal and colonialist domination. Heim Lafrombois (2018: 11), considering Chicago, reflects on what she calls 'Do-It-Yourself Urbanism' from an intersectional feminist perspective, exploring the ways in which race, gender, class and sexuality intersect in how communities are shaped and policies made.

The challenge comes when different concerns vie over whose pain is more authentic, relativising or delegitimising the pain of the other. In an intersectional approach, different struggles are considered part of a broader struggle to reclaim our common humanity through justice that makes whole. This is very pertinent in urban contexts where most of these topics overlap in complex ways and need to be considered, interpreted and tackled in interconnected ways, if deep transformation is the desire. The kind of learning that could occur through an honest desire to be in solidarity with others' struggles is immeasurable. At the same time, sites of marginality, once interconnected with important other sites, start amplifying silenced cries and imagined alternatives in much more visible ways. Urban struggles for justice give voice and expression to the longing for wholeness - overcoming fractures, exclusions and isolations - in the deepest sense of the word. Planning education would do well to help future planners wrestle with, and reflect on the intersectional nature of oppression, exclusion and marginalization, and help imagine liberating planning practices that are inclusionary and life-affirming for all inhabitants of an area or region.

\subsection{Prophetic anger and lament}

Hopeful communities are resistant communities, naming that which 'deals death' (social exclusion, physical displacement, socio-spatial inequalities, or lack of access to affordable resources), and imagining and calling forth that which announces life (social inclusion, secure tenure, socio-spatial equality, and increased access to affordable resources). Hope is found in the very resistance to that which steals hope.

Those who resist, who 'name what is wrong' and who help imagine creative alternatives are often called prophets. Fox (2000: 260) suggests that prophets carry the creative energy of God "when it has been stymied or stifled by injustice or laziness or too much belief in the immortality of what already is". The task of the prophet in the face of injustice or a negative status quo is to interfere (Heschel, 1962: 205): interfering with injustice, with spatial exclusion, with dehumanizing market forces (Fox, 2000: 261). According to Fox (2000: 260), "[t]he prophet knows something about trusting anger, trusting one's moral outrage, trusting what is intolerable and molding that anger and outrage into creative possibilities".

Baum (2015: 506) speaks of "planners' lack of interest in emotion", over-emphasizing the rationality of planning. Such facilitators of planning or participation processes have not yet learnt the creative power of anger, outrage and lament. By allowing, inviting even, such emotions into planning processes, it offers the possibility of creative and better alternatives, because we hear and address the very concerns soliciting most anger.

In this regard, it is worth considering the work of Forester, who holds a highly contrary view to dominant planning practices. Forester (1999: 203) is of the view that planners (and city-makers) should understand the emotions of others and of themselves - the "emotions of fear and suspicion, anxiety and resentment, compassion and generosity", as sources of learning and vision. As an example, Forester (1999: 203) notes the necessity of mourning in planning processes. Without this ability to lament or mourn "losses of the past", it becomes difficult to evoke imaginaries of possible alternative futures.

Katongole (2017: xviii) mentions that lament is "a decisive form of political agency"; it is "a form of resistance (against 'cheap hope') and struggle to transform the structures of violence, poverty and marginalization into an 'excess of love'". In this, Katongole (2017) suggests the impossibility to think about hope in contexts of deep violence and social unrest, without evoking and nurturing the capacity and gift of lament.

Baum (2015: 508) speaks of the deep emotions felt by those who experience urban displacement, referring to studies of such processes in places as diverse as Boston, Baltimore, Lagos, or London. With reference to the work of Fried (1963), he describes the hopelessness felt by those who were displaced, losing "attachments to people and places that gave them meaningful identities and secure relationships" (Baum, 2015: 508). The levels of trauma and loss many urban dwellers experience on a daily basis need to be considered in planning processes if we are to make more humane cities. Creating hospitable and safe spaces for such anger, pain or trauma to surface, to be lamented, and to be held, respectfully, would build the kind of trust that could birth hopeful alternative imaginations.

The majority of planners (and, by implication, the planning processes they manage) tend to dismiss emotions, not only because of their own deeply rationalistic tendencies, but also, perhaps, because of the messiness, unpredictability and complexity once emotions get involved (Baum, 2015: 511), the fact that they are mostly not prepared to deal with the emotions of the urban dwellers they plan for, and the fear to face oneself. Planners who are unable to recognize, 
reflect on, or account for their own emotions and desires, will help give birth to cities and communities that are either shaped in the image of dominant societal groups, or their professions' collective fears and preoccupations, and leave in place, replicate and/or deepen the unhealed scars of places and people alike.

\subsection{Beyond the myth of a-political urban spatial praxis}

Watson and Gibson (1995: 31) ask: "Can we create an effective postmodernism of resistance that involves more than bovine immobility or sitting on fences like Humpty Dumpties playing with words?". In answer to this question, and instead of postmodern relativism, or a-political urban engagement, urban spatial praxis that is deeply and decidedly engaged in the politics of spatial formulation and formation should be considered.

Watson and Gibson (1995: 33) refer to the work of Foucault (1975) and Lefebvre (1991) on space, and the fact that both "problematized revolution spatially around the politics of the urban, the struggles of power over the governing of space and territory that are centered in cities but extend well beyond them into the urbanized countryside and peripheries". Lefebvre (1991) spoke of a "spatial praxis" that engaged the politics of spatial formation. An 'urban spatial praxis' is never neutral, but always deeply political in how it affects people, and that justice does not happen without struggle.

For some South African planners, planning shifted from being a neutral discipline to a critical engagement that includes advocacy and resistance to a status quo that (still) excludes the lives and interests of the most vulnerable. Regrettably so, this has not been the case for most (Oranje, Venter \& Ferreira, 2018). Within contexts of spatial segregation and the perpetual reproduction of segregated spaces by the workings of neoliberal capitalist urban formation, the importance of local communities and inter-connected local movements cannot be stressed enough. They become the ones that develop robust urban spatial praxes, able to counter, or at least expose and broadcast the reality of exclusivist and death-dealing urban political and spatial processes.

\subsection{Planning: A tool of repression or of inclusion}

Planning can either be a progressive tool of inclusion and reconstruction or a tool of control and repression. Yiftachel (1995: 218) writes, with reference to the situation of IsraelPalestine: "The very same planning tools usually introduced to assist social reform and improvement in people's quality of life can be used as a means of controlling and repressing minority groups". There is a clear comparison between Israel-Palestine nowadays and the socio-spatial oppressions faced by Black South Africans in pre-1994 urban South Africa. Planners in such contested regions face great difficulty, since planning is often used to further oppression and marginalization, making planners deeply complicit (Allegra, 2016).

Comparative notes should also be made in terms of the ways in which planning policy and procedures impact on a daily basis upon homeless communities, refugees, those living with disability, and the poor in general. Planners are either complicit in the marginalization of vulnerable groups, or able to facilitate their inclusion.

The lack of relationships between mainstream planners and particularly vulnerable urban neighbourhoods keeps such planners largely in oblivion to the emotions and aspirations of the majority of South Africa's urban dwellers. Their planning, however ambitious, progressively-prosaic and/or professional as it might be, does not speak of the existential challenges or emotional trauma of vulnerable urban people. Even if not outright an example of repressive planning, what they mediate is hardly inclusive, and tends to, at the very least, repress emotions of anger, frustration, loss, or powerlessness. It way too often succeeds only in taking away the scanty power local communities managed to build up through their own actions.

In this regard, Yiftachel (2009) speaks of resistance and the "mobilization of the colonized" in situations where spatial production is oppressive. It needs to be discerned daily in how ordinary people struggle to access the city and its resources. Planning, therefore, if not to be a tool of repression and control, must become a tool of resistance and the mobilization of those who become and remain victims of neocolonial urban spatialities, assisting communities to gain or reclaim their own agency for making change on their own terms. Matters in urban and rural space are never neutral.

\subsection{Resistance starts with us}

Resistance starts with us and in us, right here and right now where marginality and exclusion are so real and so harshly experienced. It starts in communities of struggle and solidarity. Once we become aware of the forces that marginalize some, and how we all are often so complicit in this regard through deeply ingrained practices and processes, we can no longer pretend to be ignorant or innocent. Once we embark on a journey of solidarity, we too must be liberated and transformed in terms of our own consciousness, identity, language, practices and postures.

Walking the walk, in this case, decidedly also requires talking the talk. Real prophets are nonelitist in how they speak and act, representing a "street spirituality, one that the nonprofessional person can understand" (Fox, 2000: 263). This requires an artistry, calling "forth symbols of justice and injustice that are universally recognizable" (Fox, 2000: 263). If planners, educators, theologians, lawyers, business people, scientists or artists can only be understood by professional people from their own disciplines, then Fox (2000: 264) asks: "Whom are you serving?". 
If the language we use is inaccessible to those living on the streets and in marginalised and generally forgotten city neighbourhoods, we are neither prophetic, nor wise (Fox, 2000: 264). Fox (2000: 264) suggests, therefore, that the prophetic task of professionals should start within their own profession, "to start transforming that particular profession so that it serves the oppressed and ceases to legitimize the oppressor". By doing so, Fox (2000: 264) argues that "[m]any professionals today will find their prophetic calling precisely in de-elitizing their own profession".

The question arises whether those that are marginalized need and/ or want planners to side with them. In order to correct past and current wrongs and exclusions, facilitated by planning, and to counter the greed of those who seek to expand and profit at the cost of small people and communities, some would need to side with those who are victims of urban 'growth'. Once small communities take ownership for their own life together, they too need planners to accompany the imaginations from within and from below, into concrete and alternative irruptions, countering the status quo.

Ellin (1996: 71) spoke of the shift in planning praxis of the 1960s and 1970s towards more selfcritical and reflective planning and architecture. In some circles within these disciplines, the professionals became less authoritarian, humbler in recognising themselves as one actor in the planning arena, and more overtly political, with the goal of empowering people to improve their communities and their environment. Rather than simply designing and realizing plans, these architects and planners would also engage in a critical examination of the status quo and in becoming advocates for unrepresented interests.

Resistance starts with us - and how we deliberately seek to disentangle ourselves from being complicit in forces robbing communities of agency. Yet, city-making from below could not only engage in resistance, as that would have paralyzing effects. Small communities also need to develop the capacity to engage in concrete acts of reconstruction.

\section{ON RECONSTRUCTION}

Krier (1984, in Grant 2006: 26) proposes a charter for reconstructing the city as "a moral project that mirrors a political constitution". Krier's proposal (1984) indicates that reconstruction is never neutral. It implies a certain political and ethical position, consciously or unconsciously.

\subsection{Reconstruction as resistance}

In the run-up to, and in post-1994 democratic South Africa, the idea of reconstruction became central in planning theory, government policy documents and a number of theological discourses (Oranje, 1997: 180; Villa-Vicencio, 1992; RSA, 1994)". This was accompanied by a new focus on housing, public participation, and a new sensitivity for the sociopolitical context within which planning was done. Oranje (1997: 80; 2014) suggests that this passion faded away in planning as soon as the feelgood euphoria of post-Apartheid South Africa passed, with an empty, repetitive, soulless planning discourse on transformation and progressive change taking its place.

This article affirms the role of small communities in taking ownership of the processes involved in shaping hopeful futures for themselves. Communities of hope are never simply resistant communities, but - as embodiments of an alternative political imagination - such communities also seek to contribute concretely to the reconstruction of the city. They do so not only in terms of socio-spatial, economic, ecological and institutional infrastructure, but also in terms of public policy and processes that could help shape the city and its future. Reconstructive actions in themselves could be actions of resistance, if they help overcome the "pessimism, cynicism, and despair" (Fox, 2000: 264) that sometimes take hold of us, our communities, or public discourse, and choose to "channel moral outrage into rebirth" (Fox, 2000: 264).

An example is the rehabilitation of abandoned buildings into dignified housing by Common Ground in New York City, accommodating former homeless people and integrating them fully into local social networks and the economy. Their model is not only providing sustainable tenure to formerly homeless people, reconstructing the local urban landscape, but also resisting the notion that homeless people cannot be reintegrated meaningfully, that they will affect surrounding market prices detrimentally, and that it is more expensive to house homeless people decently than to displace them into institutional care models (prisons, hospitals, psychiatric hospitals). In fact, they demonstrate the contrary as true, in viable and sustainable ways into institutional care models, such as prisons, hospitals and psychiatric institutions.

Other examples include innovative and transformative slum-upgrading projects in Manila ${ }^{7}$ or Addis Ababa, ${ }^{8}$ done from below and from within communities; alternative justice models in Manhattan, New York City; ${ }^{9}$ creative approaches to deal with waste management ${ }^{10}$ in Curitiba, Brazil or Cairo, Egypt, or the reconstruction of inner city sites in Johannesburg or Pretoria for socially inclusive housing, demonstrating the alternative possibilities to socially exclusive urban regeneration.

7 Beltran (2012) describes the transformation of Smokey Mountain in Manila.

8 Endria (2009) describes quality of life improvement and slum upgrading processes through one community development organisation - IHA-UDP - in Addis Ababa, Ethiopia.

9 See the Center for Court Innovation (n.d.) and Restorative Justice Initiative (2018), both located in New York City.

10 Braga (1993) describes solid waste management solutions in Curitiba and De Beer (2014) reflects on the impact of the Zabbaleen community on waste management in Cairo. 


\subsection{Equity planning as solidarity with marginal places and people}

Krumholz and Clavel (1994) speak of "equity planning" as simultaneously resisting and reconstructing resisting in its solidarity with those often excluded and lacking access, but doing so constructively, through specific interventions aimed at long-term and hopeful change. Equity-based approaches to planning "hold the promise of better policy and benefits for troubled neighbourhoods and at-risk populations within cities" (Krumholz \& Clavel, 1994: xiv). 'Conventional planners' often allow their ends to be decided by politicians, planning boards and business, allowing political pressure based on the assumption that politicians "represent the people through the democratic process" (Krumholz \& Clavel, 1994: 3).

Equity planners, in how Krumholz and Clavel (1994: 3 ) describe this approach, reject such a narrow definition of what planners are supposed to be and do. Equity planners argue that planners who seek a better future for the cities and their people must be concerned with both the ends and the means. They show deep concern for the "truly disadvantaged", because equity planners assume that the existing democratic institutions are biased against the interests of those at the bottom of the social system. They, therefore, actively seek to mediate downward redistribution (Krumholz \& Clavel, 1994: 3).

Equity planning could also be regarded as restitutive planning. In contexts where the planning profession contributed to an unequal society, both as institution and in institutionalizing socio-spatial inequity, the same profession has the responsibility to do restitution through equity planning.

\subsection{Redistributive reconstruction: On abundance and inclusion}

The kind of reconstruction that is implicitly resistant will be a 'redistributive reconstruction'. Such reconstruction works from the premise that there is an abundance of resources in the city instead of perpetuating the myth of scarcity (Covey, 1989). Castells (2017) and Fioramonti (2017) thoroughly and convincingly explore the idea of viable alternatives to scarcity economies. The question is not one of scarcity or adequacy, but one of (fair) distribution and (equal) access.

"Equity planning [makes] a conscious attempt to devise redistributive policies in favour of the least powerful and to enhance the avenues of participation" (Krumholz \& Clavel, 1994: 1). In Krumholz and Clavel's (1994: 1) view, city policy should be explicit about "providing choices to those who had few". In their focus on participation of excluded neighbourhoods and groups, equity planners deal intentionally with issues of diversity, race and class, seeking to respond to the political and economic coalitions that estranged the poor from society's institutions (Krumholz \& Clavel, 1994: 3-4).

In the United States of America, in the 1960s and 1970s, there was a lively interest in the related approaches of advocacy planning, social planning, community planning, or equity planning (Krumholz \& Clavel, 1994:15). Currently, in South African cities and towns marked by intense levels of disparity, there is an ongoing need for planners and city-builders who will intentionally position themselves with marginal people and places and with small, local communities to help facilitate equitable-redistributive reconstruction. This, however, does not seem to be where (the majority of) planners want to be, and hard questions need to be asked as to why this is the case.

\subsection{Appreciating local communities, optimizing hopeful alternatives}

Fragmentation, fear and individualism have in many cases eroded a sense of the city as a community of interrelated, interdependent communities. The legacy of the Apartheid City, and its deep socio-spatial-political fracture, remains deeply etched into the urban fibre of South African cities.
The perpetuation of socio-spatial segregation continues to destroy the possibility of interconnected communities. The widespread gentrification processes colonizing depressed inner-city neighbourhoods have become a serious threat to the poor communities living in those neighbourhoods.

Yet, it is precisely amidst such urban fracture and disparity that we need to recognize the robust irruptions of communities from below, reclaiming what they have lost, or holding on tenaciously to what they still risk losing. Every city seems to have such communities, and often there is remarkable vision and energy in these places. City-builders and planners would do well to find these communities and to relate to them not only as observers and describers, but as active participants.

Such communities could be evident in faith-based communities gathering certain days of the week and wrestling to translate their faith into actions influencing the public domain positively. It could be local organizations with management, staff and administrative capacity, that are honest in their attempts to invest their institutional infrastructure in contributing to hopeful places. It could be citizens' movements - small and fragile, or large and robust - that seek to contribute to inclusive, hopeful cities.

The embedded actions of such communities often emerge from active lament over what is wrong. As such, they become hopeful communities, practising both resistance and reconstruction. Hopeful communities hold the potential to be ethical communities.
Ethics cannot be sustained outside of an ethical community: an actual, not an abstract community in which individuals learn ethical discernment and practical wisdom by direct example, practice, conversation and interaction (Greenberg, 1995: 14).

Furthermore, such communities, in which citizens participate in the life of the city ethically and constructively, become communities of hope, or "a generative, creative force" (Greenberg, 1995: 41). Hopeful 
communities, seeking to act ethically together, do so with the view of contributing to 'a hopeful city' in which all people will have access to sources of sustainable livelihood, and in which no-one will be excluded from the collective urban household.

DeFilippi and North (2004) caution against factors that can reduce the emancipatory potential of such communities. According to them, while difference needs to be embraced and negotiated, the emphasis must not only be on difference, but also on finding commonality; the imposition of ideal images of communities may damage their emancipatory potential; 'successful communities' must guard against co-option by local governments, donor organisations and others into processes that might be detrimental to their longer term aspirations and emancipation; skills must not be hoarded by community leaders, but transferred to, and built in other members of the community; and care must be taken, as communities get more 'official' attention and gain more confidence, to avoid conflicts arising between the more activist and the more conservative members of such communities (DeFilippi \& North, 2004: 4, 74, 82-86).

\section{MOVEMENTS OF INTERCONNECTED COMMUNITIES}

There was an earlier reference to Harvey's concern that urban social movements lack coherence and unity. Cone (2001: 24) echoes this:

\begin{abstract}
Justice fighters for black people and the defenders of the earth have tended to ignore each other in their public discourse and practice. Their separation from each other is unfortunate because they fight the same enemy human beings' domination of each other and nature.
\end{abstract}

Add to this the strong assertion by Jung (1993) that those who advocate the environment without concern about the oppression of women, and those who advocate issues of women's oppression without being concerned about the environment are both practising an inadequate ethic.
In addition to this, Cone (2001: 27) demonstrates, with reference to a report of the United Church of Christ entitled "Report on Race and Toxic Waste in the United States" (1989), that race was an important indicator of where hazardous waste facilities could be found in the United States: "Forty percent of the nation's commercial hazardouswaste landfill capacity was in three predominantly African-American and Hispanic communities".

The clear message from all of this is that it would seem that those working for justice in different spheres - race, gender, environment, land, poverty - often work in isolation from each other, and yet share the common denominator of social oppression by the strong against the weak. Given the intersectionality of justice concerns, the calls by Jung, Cone, Harvey and many others should be supported, when they argue for new collaborations where the different communities seeking justice and hope would be interconnected into larger, stronger and more effective movements of and for change.

In the 1990s, Watson and Gibson (1995: 260) spoke of the shift from class politics to identity politics, whereby people organize themselves in terms of race, gender, class, sexuality and other such categories. The danger of such delineation and organizing is that it tends to create new homogeneities, excluding some/ others and disallowing diversity and difference. What is rather required at present is movements that bring together diverse interests in solidarity with each other, building alliances beyond narrow self-interest for the sake of the common good.

This is a call for a new politics of alliances, partnerships and collaborations that go beyond traditional divides or binary oppositions, as so aptly put by Watson and Gibson (1995: 262):

Instead of assuming single subject positions it is now commonplace to recognize that people represent several groups at once and occupy multiple subject positions and identities which shift and change all the time. Postmodern politics allows for optimisms and possibility since it celebrates struggles and new possibilities at many sites both marginal and mainstream.

Our contemporary cities need local communities of hope, acting ethically, whilst fostering movements of interconnected communities and intersectional themes, standing together for justice. If resistance can be practised with effect in local neighbourhoods and radical transformations be demonstrated, these movements could indeed guide and shape city-wide movements in terms of strategy and tactics, alternative imaginaries and hopeful models of 'the possible'.

Perhaps the biggest caution raised by DeFilippi and North (2004: 75-77) is, drawing on Marxian and feminist critiques of community, that a local, community-based approach might fail to acknowledge the deeper structural and class-based exclusions in society. This, together with the relative impact of small local communities - because of size, capacity, resources or locality - requires the discernment of similar communities across the/a city, building strategic and deliberate solidarity, until an interconnected movement of hope can emerge.

Local and global movements of interconnected communities can serve as mediators of hope in as far as they engage in the actual sites of resistance, generating knowledge whilst being immersed, and learning from each other's concerns and aspirations. Their acts of solidarity and resistance - if not selfish acts, but genuinely seeking the common good and the city's wholeness - will help (re)construct radical cities marked by participatory democracy (Watson \& Gibson, 1995: 257).

Urban spaces, in which such movements function, will be less privatized, enabling individuals to interact in the open, expressing both their differences and their commonalities. These spaces will not be bound by boundaries or borders creating spaces of exclusion and inclusion - they will be spaces without walls" (Watson \& Gibson, 1995: 261). 


\section{CELEBRATING RESISTANCE, LONGING FOR WHOLENESS}

Soelle (1993) speaks of the hope of vulnerable people in Latin America, defying the odds, often through employing ritual or festivals to resist life-denying forces. Although this article is born from a lament over the exclusion of small communities and voices from dominant citymaking practices, it concludes on a more celebratory note. Nowadays, festivals and diverse expressions of art and beauty, coming from within communities, are offering not only social critique, but often are attempts at reclaiming that which was lost. Such expressions, combined with creative, colourful and non-violent forms of protest, are celebratory forms of resistance, seeking to reconstruct what is fractured, longing for wholeness.

This article sought to make a case for small communities practising resistance and reconstruction, grounded in a different political imagination of local agency. In doing so, it argues that such communities, aware of the forces that would seek to tear them apart, can play a significant role in 'making cities from below'. This would become even more likely through such communities finding each other, and nurturing deep and lasting solidarities, until broad-based, interconnected movements take shape, embodying concrete signs of wholeness.

Every time communities and movements - small, interconnected and local - intervene in the dominant expressions of market and capital, and by doing so create accessible and alternative options, they celebrate resistance to the vile, footloose neoliberal gods of greed and materialism. As such, they demonstrate the possibility of alternatives and of the 'there-ness', power and practicability of options where others, notably professional planners saw, let alone 'imagined', none. They reclaim the power of community to sustain what is 'really' under threat - 'all of us and all of our lives together'. In this, they give expression to a deep and ceaseless longing for wholeness (Alexander, Anninou, King \& Neis, 1987), occasionally becoming visible, pushing through the fractures of urban disconnect, and asking only of us as planners to widen the crack and break the/our mould, so that we can also become whole again.

\section{REFERENCES}

ALEXANDER, C., ANNINOU, A., KING, I. \& NEIS, H. 1987. A New theory of urban design. New York: Oxford University Press.

ALLEGRA, M. 2016. Planners amidst the storm: Lessons from Israel/ Palestine. Planning Theory and Practice, 17(3), pp. 476-479. https://doi. org/10.1080/14649357.2016.1195087

BALLARD, R., HABIB, A. \& VALODIA, I. (Eds). 2006. Voices of protest: Social movements in post-apartheid South Africa. Pietermaritzburg: University of KwaZulu-Natal Press.

BAUM, H. 2015. Planning with half a mind: Why planners resist emotion. Planning Theory \& Practice, 16(4), pp. 498-516. DOI: http://dx.doi.org/10.1080/ 14649357.2015.1071870

BELTRAN, B.P. 2012. Faith and struggle on smoky mountain: Hope for a planet in peril. Maryknoll, NY: Orbis Books.

BOFF, L. 1997. Cry of the earth, cry of the poor. Maryknoll, NY: Orbis Books.

BRAGA, C.B. 1993. Solid waste management in Curitiba, Brazil - alternative solutions. Journal of Resource Management and Technology, 21(1), pp. 11-14.

CASTELLS, M. 2017. Another economy is possible: Culture and economy in a time of crisis. London: John Wiley and sons.

CENTER FOR COURT INNOVATION. [n.d.] Midtown Community Court. [online]. Available at: <https://www. courtinnovation.org/programs/ midtown-community-court> [Accessed: 8 April 2019].

COBURN, A. \& GORMALLY, S. 2015. Emancipatory praxis: A socialjustice approach to equality work. In: Cooper, C., Gormally, S. \& Hughes, G. (Eds). Socially-just, radical alternatives for education and youth work practice: Re-imagining ways of working with young people. London: Palgrave Macmillan, pp. 65-84. DOI: 10.1057/9781137393593_4

CONE, J. 2001. Whose earth is it anyway? In: Hessel, D. \& Rasmussen,
L. (Eds). Earth-habitat: Eco-injustice and the church's response. Minneapolis, MN: Fortress Press, pp. 23-32.

COVEY, S. 1989. Principle-centered leadership. New York: Simon \& Schuster.

CRENSHAW, K. 1989. Demarginalizing the intersection of race and sex: A Black feminist critique of antidiscrimination doctrine, feminist theory and antiracist politics. University of Chicago Legal Forum, 140, pp. 139-167.

DE BEER, S.F. 2014. Jesus in the dumping sites: Doing theology in the overlaps of human and material waste. HTS Teologiese Studies/Theological Studies 70(3), Art. \#2724, 8 pages. DOI: http://dx.doi.org/10.4102/hts.v70i3.2724

DE BEER, S.F. 2017. Urban social movements in South Africa today: Its meaning for theological education and the church. HTS Teologiese Studies/ Theological Studies 73(3), a4770. https://doi.org/10.4102/hts.v73i3.4770

DE BEER, S.F. 2018. Mother bird hovering over the city: Space, spirituality and a community-based urban praxis. Ph.D. thesis. University of Pretoria, Pretoria: Town and Regional Planning.

DEFILIPPI, J. \& NORTH, P. 2004. The emancipatory community? Place, politics and collective action in cities. In: Lees, L. (Ed.). The emancipatory city? Paradoxes and possibilities. Thousand Oaks, CA: Sage, pp. 72-88. DOI: http:// dx.doi.org/10.4135/9781446221365.n5

ELLIN, N. 1996. Postmodern urbanism. New York: Princeton Architectural Press.

ENDRIA, S. 2009. A study of slum improvement intervention by integrated holistic approach - Urban development project in former Kebele 08 of Woreda 23, Addis Ababa. Masters thesis in Development Studies. Addis Ababa University, Addis Ababa.

FIORAMONTI, L. 2017. Wellbeing economy: Success in a world without growth. Midrand, South Africa: Macmillan.

FORESTER, J. 1999. The deliberative practitioner: Encouraging participatory planning processes. Cambridge, MA: MIT Press.

FOUCAULT, M. 1975. Discipline and punishment: The birth of the prison. New York: Random House.

FOX, M. 2000. Original blessing: $A$ primer in Christian spirituality. Santa Fe, NM: Bear.

FREIRE, P. 1993. Pedagogy of the city. London: Continuum.

FREIRE, P. 2007. Pedagogy of the oppressed. London: Continuum. 
FREIRE, P. 2014. Pedagogy of hope: Reliving pedagogy of the oppressed. London: Bloomsbury.

FRIED, M. 1963. Grieving for a lost home. In: Duhl, L.J. (Ed.). The urban condition: People and policy in the metropolis. New York: Simon and Schuster, pp. 151-171.

GASTROW, S. 2015. Is South Africa heading towards a new civil society? Daily Maverick [online]. Available at: <https://www.dailymaverick.co.za/ opinionista/2015-10-23-is-south-africaheading-towards-a-new-civil-society/> [Accessed: 8 March 2019].

GIROUX, H.A. 1988. Literacy and the pedagogy of voice and political empowerment. Educational Theory, 38(1), pp. 61-75. DOI: https://doi. org/10.1111/j.1741-5446.1988.00061.x

GRANT, J. 2006. The ironies of new urbanism. Canadian Journal of Urban Research, 15(2), pp.158-174.

GREENBERG, M. 1995. The poetics of cities: Designing neighbourhoods that work. Columbus, $\mathrm{OH}$ : Ohio State University Press.

HANKELA, E. 2014. Faith community as a centre of liberationist praxis in the city. HTS Teologiese Studies/ Theological Studies, 70(3), Art. \#2768, 9 pages. DOI: http://dx.doi.org/10.4102/ hts.v70i3.2768

HARVEY, D. 2012. Rebel cities: From the right to the city to the urban revolution. London: Verso.

HEIM LAFROMBOIS, M.E. 2018. Reframing the reclaiming of urban space: A feminist exploration into do-it-yourself urbanism in Chicago. New York: Lexington Books.

HESCHEL, A.J. 1962. The prophets. New York: Harper \& Row.

HOOKS, B. 1999. Yearning: Race, gender and cultural politics. New York: South End Press.

JUNG, S.L. 1993. We are home: $A$ spirituality of the environment. New York: Paulist Press.

KATONGOLE, E. 2017. Born from lament: The theology and politics of hope in Africa. Grand Rapids, MI: Wm B. Eerdmans Publishing Co.

KRIER, L. 1984. Houses, palaces, cities. London: Academy Publications.

KRUMHOLZ, N. \& CLAVEL, P. 1994. Reinventing cities: Equity planners tell their stories. Philadelphia, PA: Fortress Press.
KRUMHOLZ, N. \& HEXTER, K.W. (Eds). 2019. Advancing equity planning now. New York: Cornell University Press. DOI: https://doi. org/10.7591/9781501730399

LEDWITH, M. 2007. On being critical: Uniting theory and practice through emancipatory action research. Educational Action Research, 15(4), pp. 597-611. DOI: https://doi. org/10.1080/09650790701664021

LEDWITH, M. 2011. Community development: A critical approach. $2^{\text {nd }}$ edition. Bristol: Polity Press.

LEFEBVRE, H. 1991. The production of space. Cambridge, MA: Blackwell.

MADLINGOZI, T. 2007. Post-apartheid social movements and the quest for the elusive 'new' South Africa. Journal of Law and Society, 34(1), pp. 77-98. DOI: https://doi. org/10.1111/j.1467-6478.2007.00383.x

METZGER, J.T. 1996. The theory and practice of equity planning: An annotated bibliography. Journal of Planning Literature, 11(1), pp. 112-126. DOI: https://doi. org/10.1177/088541229601100106

NIXON, D. 2014. Towards a theology of urban regeneration: Stories from Devonport. International Journal of Public Theology, 8(2), pp. 223-245. DOI: https://doi. org/10.1163/15697320-12341343

OLVER, C. 2017. How to steal a city. The battle for Nelson Mandela Bay. Cape Town: Jonathan Ball Publishers.

ORANJE, M. 1997. The language game of South African urban and regional planning: A cognitive mapping from the past into the future. Unpublished Ph.D. thesis. University of Pretoria, Pretoria: Town and Regional Planning.

ORANJE, M. 2014. Back to where it all began ...? Reflections on injecting the (spiritual) ethos of the Early Town Planning Movement into Planning, Planners and Plans in post-1994 South Africa. HTS Teologiese Studies/ Theological Studies, 70(3). Art. \#2781, 10 pages. [online]. Available at: http:// dx.doi.org/10.4102/hts.v70i3.2781 [Accessed: 10 June 2018].

ORANJE, M., VENTER, S. \& FERREIRA, A. 2018. Good intentions, deep frustrations and upward mobility: Just another young planner's day in South Africa. In: Tasan-Kok, T. \& Oranje, M. (Eds). From planning student to urban planner: Young practitioners' reflections on contemporary ethical challenges. New York: Routledge, Chapter 6 (e-book). DOI: https://doi. org/10.4324/9781315726854-6
PIETERSE, E. \& SIMONE, A.M. 2013.

Rogue urbanism: Emergent African cities. Johannesburg, South Africa: Jacana Media.

RESTORATIVE JUSTICE INITIATIVE. 2018. [online]. Available at: <http://www. restorativejustice.nyc/> [Accessed: 8 April 2019].

ROCKE, K. \& VAN DYKE, J. 2012. Geography of grace: Doing theology from below. Tacoma, WA: Street Psalms Press.

RSA (REPUBLIC OF SOUTH AFRICA). 1994. White Paper on Reconstruction and Development. Cape Town: Ministry in the Office of the President.

SHANNAHAN, C. 2013. The Canaanite woman and urban liberation theology. The Expository Times, 125(1), pp. 13-21. DOI: https://doi. org/10.1177/0014524613498673

SHAPER, D. 1989. A book of common power. San Diego, CA: LuraMedia.

SOELLE, D. 1993. Celebrating resistance: The way of the cross in Latin America. London: Mowbray.

SWYNGEDOUW, E. 2002. The strange respectability of the situationist city in the society of the respectable. International Journal of Urban and Regional Research, 26(1), pp. 153-165. DOI: 10.1111/1468-2427.00369

VILLA-VICENCIO, C. 1992. A theology of reconstruction: Nation-building and human rights. Cambridge: Cambridge University Press. DOI: https://doi. org/10.1017/CBO9780511607592

WATSON, V. 2002. The usefulness of normative planning theories in the context of Sub-Saharan Africa. Planning Theory, 1(1), pp. 27-52. DOI: https:// doi.org/10.1177/147309520200100103

WATSON, S. \& GIBSON, K. (Eds). 1995. Postmodern cities and spaces. Oxford: Blackwell.

YIFTACHEL, O. 1995. The dark side of modernism. In: Watson, S. \& Gibson, K. (Eds). Postmodern cities and spaces. Oxford: Blackwell, pp. 216-242.

YIFTACHEL, O. 2009. Critical theory and 'gray space'. Mobilization of the colonized. City, 13(2-3), pp. 240-256. DOI: 0.1080/13604810902982227 